\title{
ANALYSIS OF HEALTH SERVICE RETRIBUTION RATES FOR PRIMARY HEALTHCARE CENTERS IN CIMAHI CITY
}

\author{
Budiman $^{1}$, Ayu Laili Rahmiyati ${ }^{1}$, Lina Safarina ${ }^{1}$ \\ ${ }^{1}$ Faculty of Science \& Health Technology. \\ University of Jenderal Achmad Yani Cimahi, Cimahi, Indonesia \\ Correspondence Address: Budiman \\ Email: budiman_1974@yahoo.com
}

\begin{abstract}
Retribution Tariff of Public Health Center (Puskesmas) in Cimahi City is regulated according to Regulation of Retribution Tariff according to Regulation No. 8 Year 2011. Based on the tariff value from 2011 until now still valid with same tariff. Based on the above, it is necessary to evaluate the tariff compared with the increase of the price of health equipment and the operational cost of other puskesmas supporting the puskesmas service, which increases annually.. The purpose of this research is to analyze the tariff of puskesmas. This research method is qualitative descriptive research. Result of research indicate that tariff of puskesmas service there are several alternatives along with the increase of tools, drugs and raw materials, this becomes the base of tariff policy consideration, with consideration of price increase of puskesmas tariff or addition of health budget subsidy in Cimahi City. Conclusion: Based on the unit cost of indirect cost calculation tariff of public health service Rp 26,973, -. Based on the total cost (total cost) of public health services Rp 62,529, - Based on the comparison of other city tariffs from the mayor regulation of 2011-2012 is Rp 2000, - to Rp 4000, -. Based on the proposals from the Disccusion Focus Group (FGD), several public health centers in Cimahi City, on average, were Rp 8,500. Based on the academic proposal, the average inflation rate $(R p 11,000)$, ability to pay ( $R p=9,475,-)$ cost $(R p$ 11,507), generic drug cost $(\operatorname{Rp} 6,556,-)$, average proposals of puskesmas ( $R p$ 8,500, -), namely: Rp 11,567, rounded $\operatorname{Rp} 11.000,-$
\end{abstract}

Keywords: Analysis, Retribution Tariff of Puskesmas

\section{INTRODUCTION}

The National Health Insurance Policy (JKN or Jaminan Kesehatan Nasional) and primary healthcare centers are handled by the Regional Public Service Agencies (Badan Layanan Umum Daerah). This agency has abolished the exemption of health fees for residents who seek treatment at primary healthcare centers. In 2007 there was a budget for the exemption of health care costs for residents, but in 2014 with the existence of the National Health Insurance Policy by the Social Security Agency for Health, budget allocations for health centers continued to decrease every year, such that health centers had to charge treatment fees for residents who were not registered to the Social Security Agency for Health.

According to the Ministry of Health Regulation No.75 of 2014, a primary healthcare center is a health service facility that organizes public health efforts and first-level individual health efforts, by prioritizing promotive and preventive efforts, to achieve the highest public health status in its working area. National health policy in Indonesia has experienced a shift from an illness paradigm to the healthy paradigm. Health is considered as an investment so health service institutions, including primary healthcare centers, must be able to adapt to these changes.

In providing these health services, primary healthcare centers have shown many successes. The coverage of primary healthcare centers services, in general, is quite broad, such as immunization coverage, weighing children under five, examination of pregnant women, and others. However, it is still felt that the quality of service provided is unsatisfactory. Many people complain that visits or utilization is low. The lack of quality is due to several things, including 
non-compliance with service standards, limited

personnel/supplies/medicines/financing, and weak management.

The development and operation of primary health care facilities would cost money. The fees required can come from a variety of sources, such as the government, donations, or clients. However, we often do not know the number of costs required for these activities, as well as how much of the tariff charged will be applied to these facilities. Tariff setting policy without taking into account of the unit cost of each revenue center could potentially result in great losses. The policy for determining the tariff for primary healthcare centers takes into account the basics of calculating tariffs by the government, and is conducted through various stages of consideration of both cost and non-cost factors, such as the ability and willingness to pay the community. Analysis of the ability to pay a family is measured by tracking the income and expenses of the family.

There is often a conflict between the community and the company in regard to the determination of the tariff for health services. Society, in general, wants a low tariff for health services in accordance with their ability to pay, but they also still have the expectation of high quality and satisfactory health services. However, to improve the quality of health services, more funds are needed to construct better primary healthcare centers. This requires government subsidies and great management of available funds (Devine, O'clock and Lyons, 2000). Nevertheless, the citizen's level of ability to pay on average is higher than their willingness to pay, so it can be said that they are able to pay for their own health services.

In Cimahi City, the level of community's ability and potential of willingness to pay is also different. This affects the determination of health service tariff policies. The city of Cimahi also has regional autonomy since 2001, therefore the local government's administration is entirely left to the regions. One of the activities that must be conducted by local governments is the provision of basic health services. Health problems in districts and cities are the responsibility of all citizens and the local health office as the managing agency.

The management of health services, especially at the basic level with primary healthcare centers, require a strategic effort to improve the quality of health services. Improving the quality of health services at primary healthcare centers requires funding to support the success of primary health services. One of the factors that influence funding is the existence of a health service tariff policy. The determination of the tariff policy must take into account various costs, both operational and non-operational. Funding is not only needed for current operational needs but would also changes public health status, according to patient needs and requests.

According to Subirman's research (2013), the determination of rational rates is done by analyzing unit costs, which is based on fixed costs, semi-fixed costs, and variable costs from secondary data. For the funding of primary healthcare centers, it is necessary to consider several aspects including ongoing operational costs, such as salaries for logistics suppliers, taxes, as well as maintenance costs, and costs for improving the service quality (Sabirman, 2013).

\section{METHODS}

This research method is qualitative descriptive research. Techniques Data collection with observation, in-depth interviews, Focus Group Discussion (FGD) and document review, and then processing data. Variabel of research are Direct cost and Indirect cost of clinic service at 
Puskesmas Cimahi City, with informans are Head of Puskesmas.

\section{RESULTS}

Direct Costs

The direct costs calculated in this study are the costs of medicine that are most often given to patients at primary healthcare centers, to illustrate of the direct costs that are taken into consideration in formulating tariffs. The following are the medicine costs found by calculating the use of medicine per month and compared with the average monthly visits.

Table 1. Simulation of Treatment Polyclinic Tariffs

\begin{tabular}{cccccc}
\hline Variables & $\begin{array}{c}\text { Monthly drug } \\
\text { use }\end{array}$ & $\begin{array}{c}\text { Average } \\
\text { monthly visits }\end{array}$ & $\begin{array}{c}\text { Average } \\
\text { need per } \\
\text { patient } \\
\text { (IDR) }\end{array}$ & $\begin{array}{c}\text { Total } \\
\text { Regional } \\
\text { Regulation } \\
\mathbf{2 0 1 1} \text { (IDR) }\end{array}$ & $\begin{array}{c}\text { \% Increase } \\
\text { in }\end{array}$ \\
\hline Treatment & $\begin{array}{c}\text { polyclinic20,6 } \\
66.469\end{array}$ & 1796 & 11,507 & 10,000 & 15 \\
\hline
\end{tabular}

In Table 1 above, the average monthly use of drugs at primary healthcare centers are IDR 20,666.469. If calculated by estimation, the average drug requirement per patient is IDR 11,507. The direct costs were calculated based on the costs directly incurred to the patient of a unit. In this study, the simulation for direct cost was conducted for the treatment of cough patients and toothaches, as they are the treatments most often served at the primary healthcare centers. Most of patients at the primary healthcare centers also have upper respiratory infections (Akbar, Setyaningrum and Estiningsih, 2017).

Table 2. Calculation of Direct Cost Simulation for Cough Medicine

\begin{tabular}{|c|c|c|c|c|c|c|}
\hline No. & Action Type & $\begin{array}{l}\text { Antibiotics } \\
\text { (IDR) }\end{array}$ & $\begin{array}{l}\text { Antipyretic } \\
\text { (IDR) }\end{array}$ & $\begin{array}{l}\text { Cold } \\
\text { Medicine } \\
\text { (IDR) }\end{array}$ & Allergy & $\begin{array}{c}\text { Total } \\
\text { Direct } \\
\text { Costs (IDR) }\end{array}$ \\
\hline \multirow[t]{2}{*}{1} & General Poli & $\begin{array}{l}\text { Cefixim: } \\
32,000\end{array}$ & $\begin{array}{l}\text { Pamol: } \\
900,-\end{array}$ & $\begin{array}{l}\text { acetylcysteine } \\
: \\
2,556\end{array}$ & $\begin{array}{l}\text { CTM: } \\
100\end{array}$ & 35,556 - \\
\hline & & $\begin{array}{l}\text { Amox: } \\
2,800\end{array}$ & $\begin{array}{l}\text { Pamol: } \\
900\end{array}$ & $\begin{array}{l}\text { acetylcysteine } \\
: \\
2,556\end{array}$ & $\begin{array}{l}\text { CTM: } \\
100\end{array}$ & $6,356-$ \\
\hline
\end{tabular}

Based on the calculation of cough treatment simulation in the general polyclinic, the price of Cefixime antibiotic was higher at IDR 35,556, while Amoxilin was IDR 6,356.

Table 3. Simulation Calculation of Toothache Medicine

\begin{tabular}{lllll}
\hline Type of Action & $\begin{array}{c}\text { Antibiotics } \\
\text { (IDR) }\end{array}$ & \multicolumn{1}{c}{$\begin{array}{c}\text { Antipyretic } \\
\text { (IDR) }\end{array}$} & $\begin{array}{c}\text { Anti- } \\
\text { inflammatory } \\
\text { (IDR) }\end{array}$ & $\begin{array}{c}\text { Total Direct Costs } \\
\text { (IDR) }\end{array}$ \\
\hline Dental & Clinic & Pamol: & Dexa: 0.300 & 33,200 \\
& Cefixim: & 0.900 & & \\
& 32,000 & & & 4,000 \\
& Amox: & Pamol: & Dexa: 0.300 & \\
& 2,800 & 0.900 & & \\
\hline
\end{tabular}

Based on the simulation calculation for toothache treatment served at primary healthcare centers, the total direct cost incurred for cefixim, antipyretic, and anti- 
inflammatory antibiotics were higher at $\mathrm{Rp}$

33,200 compared with amox.

Table 4. Calculation of Unit Cost in General Polyclinics in 2017

\begin{tabular}{|c|c|c|c|c|c|c|}
\hline $\begin{array}{l}\text { Type } \\
\text { Action }\end{array}$ & $\begin{array}{l}\text { Total } \\
\text { Direct } \\
\text { Cost } \\
\text { IDR }\end{array}$ & $\begin{array}{l}\text { Cost } \\
\text { IDR }\end{array}$ & $\begin{array}{l}\text { Total } \\
\text { Cost } \\
\text { IDR }\end{array}$ & $\begin{array}{lr}\text { Old } & \text { Tariff } \\
\text { Based } & \text { on } \\
\text { Local } & \\
\text { Regulation } \\
\text { IDR }\end{array}$ & $\begin{array}{l}\text { Subsidy } \\
\text { (IDR) }\end{array}$ & Description \\
\hline $\begin{array}{l}\text { Treatment of } \\
\text { cough with } \\
\text { severe } \\
\text { infection }\end{array}$ & 35,556 & 26,973 & 62,529 & 5,000 & 57,529 & $\begin{array}{l}\text { Without the } \\
\text { services of a } \\
\text { doctor. }\end{array}$ \\
\hline $\begin{array}{l}\text { Treatment of } \\
\text { cough with } \\
\text { mild } \\
\text { infection }\end{array}$ & 6,356 & 26,973 & 33,329 & 5000 & 28,329 & $\begin{array}{l}\text { Without the } \\
\text { services of a } \\
\text { doctor }\end{array}$ \\
\hline
\end{tabular}

\section{Indirect Costs}

Indirect costs are the costs that support health service activities. Before calculating indirect costs, in this study, the classification of types of expenditure based on the level of activity was determined, then the quantity of human resources or materials involved in these costs were calculated along with the tariffs. Table 5 shows the analysis of indirect costs.

Table 5. Tariffs for Imposing Indirect Costs

\begin{tabular}{|c|c|c|c|}
\hline Types of Shopping & $\begin{array}{l}\text { Number of } \\
\text { Shopping }\end{array}$ & Drivers & Cost Drivers \\
\hline \multicolumn{4}{|l|}{ Consumables } \\
\hline Office stationery & $3,200,000$ & Number of Employees & 27 \\
\hline $\begin{array}{l}\text { Electrical and electronic } \\
\text { equipment }\end{array}$ & $3,000,000$ & Number of employees & 27 \\
\hline Stamps and stamp duty & $3,000,000$ & Number of employees & 27 \\
\hline Maintenance and materials & $1,000,000$ & Floor area & 834 \\
\hline \multicolumn{4}{|l|}{ Office services } \\
\hline Telephone expenditure & $3,320,708$ & Number of employees & 27 \\
\hline Water expenditure & 555,000 & Number of employees & 27 \\
\hline Electricity expenditure & $20,000,000$ & Number of employees & 27 \\
\hline Security services & $15,000,000$ & Floor area for & \\
\hline Cleaning supplies & $15,000,000$ & Floor area for cleaning & 834 \\
\hline
\end{tabular}




\begin{tabular}{|c|c|c|c|}
\hline Types of Shopping & $\begin{array}{l}\text { Number of } \\
\text { Shopping }\end{array}$ & Drivers & Cost Drivers \\
\hline Services + spare parts & $8,850,000$ & Mileage & 900 \\
\hline Fuel & $21.150,000$ & Mileage & 900 \\
\hline Driver & $15,000,000$ & Mileage & 900 \\
\hline Printing and Copying & $2,500,000$ & Service units & 57.659 \\
\hline Procurement spending & $1,080,000$ & Service units & 57.659 \\
\hline \multicolumn{4}{|l|}{ Maintenance } \\
\hline Building and maintenance & $7,500,000$ & Floor area & 834 \\
\hline $\begin{array}{l}\text { Equipment and machinery } \\
\text { maintenance }\end{array}$ & $7,500,000$ & Number of employees & 27 \\
\hline Building's depreciation value & $51,251,002$ & The floor area of & 834 \\
\hline $\begin{array}{l}\text { Medical devices' depreciation } \\
\text { value }\end{array}$ & $87,082,757$ & Service / action & 57.659 \\
\hline $\begin{array}{l}\text { Salaries of health center } \\
\text { employees }\end{array}$ & $1,440,000,000$ & Unit service/action & 57.659 \\
\hline
\end{tabular}

The identified indirect costs were used to perform the calculation of tariff imposition of indirect costs. The discussion of indirect cost analysis was conducted by first determining the triggering factors of each cost driver, namely determining the rate of each cost by dividing the total cost by each cost driver (Harsetyanto, 2017).

Table 6. Indirect Cost Charge Rates

\begin{tabular}{|c|c|c|c|c|}
\hline Type Shop & Total & Driver & Cost Driver & Rates \\
\hline \multicolumn{5}{|l|}{ Consumables } \\
\hline Office Stationery & $3,200,000$ & $\begin{array}{l}\text { Number of } \\
\text { Employees }\end{array}$ & 27 & 118.518 \\
\hline $\begin{array}{l}\text { Electrical appliance } \\
\text { and electronic } \\
\text { equipment }\end{array}$ & $3,000,000$ & $\begin{array}{l}\text { Number of } \\
\text { Employees }\end{array}$ & 27 & 111.111 \\
\hline Stamps and stamp duty & $3,000,000$ & $\begin{array}{l}\text { Number of } \\
\text { Employees }\end{array}$ & 27 & 111.111 \\
\hline \multicolumn{5}{|l|}{ Cleaning Supplies } \\
\hline \multicolumn{5}{|l|}{ Office Services } \\
\hline Telephone expenditure & $3,320,708$ & $\begin{array}{l}\text { Number of } \\
\text { employees }\end{array}$ & 27 & 122,989 \\
\hline Water expenditure & 555,000 & $\begin{array}{l}\text { Number of } \\
\text { employees }\end{array}$ & 27 & 20,556 \\
\hline Electricity expenditure & $20,000,000$ & $\begin{array}{l}\text { Number of } \\
\text { employees }\end{array}$ & 27 & 740,740 \\
\hline $\begin{array}{l}\text { Security service } \\
\text { expenditure }\end{array}$ & $15,000,000$ & Floor area & 834 & 17,985 \\
\hline
\end{tabular}




\begin{tabular}{lllll}
\hline \multicolumn{1}{c}{ Type Shop } & \multicolumn{1}{c}{ Total } & \multicolumn{1}{c}{ Driver } & Cost Driver & Rates \\
\hline $\begin{array}{l}\text { Cleaning service } \\
\text { expenditure }\end{array}$ & $15,000,000$ & Floor area & 834 & 17,985 \\
\hline $\begin{array}{l}\text { Motor vehicle } \\
\text { maintenance }\end{array}$ & & & & \\
\hline $\begin{array}{l}\text { Service + spare parts } \\
\text { expenditure }\end{array}$ & $8,850,000$ & Mileage & 900 & 9,833 \\
\hline Fuel & $21,150,000$ & Mileage & 900 & 23,500 \\
\hline Driver & $15,000,000$ & Mileage & 900 & 16,666 \\
\hline $\begin{array}{l}\text { Shopping for Printing } \\
\text { and Copying }\end{array}$ & $20,500,000$ & Service units & 57,659 & 355 \\
\hline Procurement spending & $1,080,000$ & Service units & 57,659 & 19 \\
\hline $\begin{array}{l}\text { Maintenance } \\
\text { Expenditure }\end{array}$ & & & & 8.993 \\
\hline $\begin{array}{l}\text { Building Maintenance } \\
\text { Fees }\end{array}$ & $7,500,000$ & Floor area & 834 & 27.777 \\
\hline $\begin{array}{l}\text { Maintenance } \\
\text { equipment and } \\
\text { machinery expenditure }\end{array}$ & $7,500,000$ & $\begin{array}{l}\text { Number of } \\
\text { employees }\end{array}$ & 27 & \\
\hline $\begin{array}{l}\text { Building's depreciation } \\
\text { value }\end{array}$ & $51,251,002$ & Floor area & 834 & 1.500 \\
\hline $\begin{array}{l}\text { Medical devices' } \\
\text { depreciation value }\end{array}$ & $87,082,757$ & Service / action & 57.659 & 24.947 \\
\hline $\begin{array}{l}\text { Salaries of health } \\
\text { center staff }\end{array}$ & $1,440,000,000$ & $\begin{array}{l}\text { Unit services / } \\
\text { actions }\end{array}$ & 57.659 & \\
\hline
\end{tabular}

After the rates of the indirect costs have been determined, the next step is to calculate the amount of indirect cost allocation that will be charged as a cost per health service action. The indirect costs are allocated to the polyclinic as described above and are in accordance to the following calculation shown in table 7 .

Table 7. Indirect Cost Allocation of General Polyclinic (Adult)

\begin{tabular}{lllll}
\hline \multicolumn{1}{c}{ Type of Shopping } & \multicolumn{1}{c}{ Driver } & Cost Driver & Rates & Total \\
\hline Consumables & & & 118,518 & 474,072 \\
\hline Office Stationery & $\begin{array}{l}\text { Number of } \\
\text { Employees }\end{array}$ & 4 & 111,111 & 444,444 \\
\hline $\begin{array}{l}\text { Electrical appliance and } \\
\text { electronic equipment }\end{array}$ & $\begin{array}{l}\text { Number of } \\
\text { employees }\end{array}$ & 4 & & \\
\hline Stamps and stamp duty & $\begin{array}{l}\text { Number of } \\
\text { employees }\end{array}$ & 4 & 111,111 & 444,444 \\
\hline Cleaning Supplies & Floor area & 20 & 1,199 & 23,980 \\
\hline
\end{tabular}




\begin{tabular}{|c|c|c|c|c|}
\hline \multicolumn{5}{|l|}{ Type of Shopping } \\
\hline \multicolumn{5}{|l|}{ Office services } \\
\hline Telephone expenditure & $\begin{array}{l}\text { Number of } \\
\text { employees }\end{array}$ & 4 & 122,989 & 491,956 \\
\hline Water expenditure & $\begin{array}{l}\text { Number of } \\
\text { employees }\end{array}$ & 4 & 20,556 & 82,224 \\
\hline Electricity expenditure & $\begin{array}{l}\text { Number of } \\
\text { employees }\end{array}$ & 4 & 740,740 & $2,962,960$ \\
\hline $\begin{array}{l}\text { Security service } \\
\text { expenditure }\end{array}$ & Floor area & 20 & 17,985 & 359,700 \\
\hline $\begin{array}{l}\text { Cleaning service } \\
\text { expenditure }\end{array}$ & Floor area & 20 & 17,985 & 359,700 \\
\hline \multicolumn{5}{|l|}{$\begin{array}{l}\text { Motor vehicle } \\
\text { maintenance }\end{array}$} \\
\hline $\begin{array}{l}\text { Services + spare parts } \\
\text { expenditure }\end{array}$ & Mileage & 4 & 9,833 & 39,332 \\
\hline Fuel & Mileage & 4 & 23,500 & 94,000 \\
\hline Driver & Mileage & 4 & 16,666 & 66,664 \\
\hline $\begin{array}{l}\text { Shopping for printing } \\
\text { and copying }\end{array}$ & Service units & 48,360 & 355 & $17,167,800$ \\
\hline Procurement spending & service unit & 48.360 & 19 & 918.840 \\
\hline \multicolumn{5}{|l|}{$\begin{array}{l}\text { Maintenance } \\
\text { expenditure }\end{array}$} \\
\hline $\begin{array}{l}\text { Building Maintenance } \\
\text { Fees }\end{array}$ & floor area & 20 & 8.993 & 179.860 \\
\hline $\begin{array}{l}\text { Maintenance } \\
\text { equipment and } \\
\text { machinery expenditure }\end{array}$ & $\begin{array}{l}\text { Number of } \\
\text { Employees }\end{array}$ & 4 & 27.777 & 111.108 \\
\hline $\begin{array}{l}\text { Building's depreciation } \\
\text { value }\end{array}$ & floor area & 20 & 61.452 & $1,229,040$ \\
\hline $\begin{array}{l}\text { Medical devices' } \\
\text { depreciation value }\end{array}$ & Service / action & 48.360 & 1.500 & $72,540,000$ \\
\hline $\begin{array}{l}\text { Salaries of health } \\
\text { center staff }\end{array}$ & Service/action & units 48,360 & 24,947 & $1,206,436,920$ \\
\hline Total Indirect & & & & $\begin{array}{l}\text { Costs } \\
1,304,427,044\end{array}$ \\
\hline $\begin{array}{l}\text { Number of Actions } 1 \\
\text { Year }\end{array}$ & & & & 48,360 \\
\hline $\begin{array}{l}\text { Total Indirect Cost } \\
\text { Allocations Per Action }\end{array}$ & & & & 26,973 \\
\hline
\end{tabular}


Table 8. Comparison of Tariffs for Retribution for Health Centers in Bandung City (Bandung City Local Regulation, 2010), West Bandung Regency (Regulation, 2011), Bogor City (Regulation, 2012), and Cirebon City (Regulation, no date).

\begin{tabular}{|c|c|c|c|c|c|c|c|c|c|}
\hline $\begin{array}{l}\text { Types of } \\
\text { Health } \\
\text { Services }\end{array}$ & $\begin{array}{c}\text { Unit } \\
\text { s }\end{array}$ & $\begin{array}{l}\text { Total } \\
\text { Needs } \\
\text { (IDR) }\end{array}$ & $\begin{array}{c}\text { Tariff } \\
\text { Charg } \\
\text { ed to } \\
\text { the } \\
\text { Comm } \\
\text { unity } \\
\text { (IDR) }\end{array}$ & $\begin{array}{c}\text { Subsi } \\
\text { dy } \\
\text { (IDR) }\end{array}$ & $\begin{array}{c}\text { Tariff } \\
\text { at } \\
\text { Band } \\
\text { ung } \\
\text { City } \\
\text { (IDR) }\end{array}$ & $\begin{array}{c}\text { Tarif } \\
\text { f } \\
\text { West } \\
\text { Band } \\
\text { ung } \\
\text { (IDR) }\end{array}$ & $\begin{array}{c}\text { Tariff } \\
\text { Bogor } \\
2012 \\
\text { (IDR) }\end{array}$ & $\begin{array}{l}\text { Tarif } \\
\text { Cirebon } \\
\text { City } \\
2011 \\
\text { (IDR) }\end{array}$ & $\begin{array}{l}\text { Averag } \\
\text { e Tariff } \\
\text { Propos } \\
\text { ed } \\
\text { Health } \\
\text { Center } \\
\text { (IDR) }\end{array}$ \\
\hline $\begin{array}{l}\text { Outpatien } \\
\text { t } \\
\text { Retributi } \\
\text { on }\end{array}$ & & & & & & & & & \\
\hline $\begin{array}{l}\text { Outpatient } \\
\text { s at } \\
\text { General }\end{array}$ & $\begin{array}{l}\text { Per } \\
\text { Visit }\end{array}$ & 10,000 & 5,000 & 5,000 & 3,000 & 2,000 & 3000 & 4000 & 8,500 \\
\hline
\end{tabular}

Table 9. Proposed Tariffs

\begin{tabular}{|c|c|c|c|c|c|c|c|c|c|}
\hline $\begin{array}{l}\text { Types } \\
\text { of } \\
\text { Health } \\
\text { Services }\end{array}$ & $\begin{array}{c}\text { Tota } \\
\text { l } \\
\text { Need } \\
\text { s } \\
\text { (IDR } \\
\text { ) }\end{array}$ & $\begin{array}{c}\text { Inflati } \\
\text { on } \\
8.4 \%\end{array}$ & $\begin{array}{c}\text { Bandu } \\
\text { ng } \\
\text { City } \\
2010 \\
\text { (IDR) }\end{array}$ & $\begin{array}{c}\text { West } \\
\text { Bandu } \\
\text { ng } \\
\text { Regenc } \\
\text { y 2012 } \\
\text { (IDR) }\end{array}$ & $\begin{array}{l}\text { Bogor } \\
\text { City } \\
2012 \\
\text { (IDR) }\end{array}$ & $\begin{array}{c}\text { Cire } \\
\text { bon } \\
\text { City } \\
2008 \\
\text { (IDR } \\
\text { ) }\end{array}$ & $\begin{array}{c}\text { Propos } \\
\text { ed } \\
\text { tariffs } \\
2017\end{array}$ & $\begin{array}{c}\text { Propos } \\
\text { ed } \\
\text { Acade } \\
\text { mic } \\
\text { Rates }\end{array}$ & $\begin{array}{l}\text { New } \\
\text { Tariffs } \\
\text { for } \\
2017\end{array}$ \\
\hline $\begin{array}{l}\text { Outpati } \\
\text { ent } \\
\text { Retribu } \\
\text { tion }\end{array}$ & & & & & & & & & \\
\hline $\begin{array}{l}\text { Outpatie } \\
\text { nt at the } \\
\text { General } \\
\text { Poly }\end{array}$ & $\begin{array}{l}10,0 \\
00\end{array}$ & 11 & 3,000 & 2,000 & 3,000 & 4,000 & 8,500 & 11,000 & 11,000 \\
\hline
\end{tabular}

Comparison of Retribution Rates with Other Cities

Analysis of primary healthcare center rates was conducted by comparing the primary healthcare centers rates in Cimahi City with other cities, namely: Bandung City, Bogor City, West Bandung Regency, and Cirebon City. Adjustments were made according to the services available in each of these cities as not all cities have the same types of services and tariffs. Based on the tariff comparison above, it can be concluded that outpatient tariffs for general polyclinics in the four cities are in the range of IDR 2000 to IDR 4000 .

\section{DISCUSSION \\ Direct Cost Analysis}

Based on the simulation results, the calculation of direct and indirect costs that are often found in primary healthcare centers are for general treatment. The calculation of these costs can produce unit costs, which are the costs incurred for patients per person. The unit cost of health services at the Central Cimahi Health Center can be calculated by adding up the 
direct costs and indirect costs that we have identified and calculated in the previous section. Based on Table 6, the resulting total cost is IDR 26,973 for the treatment of coughs with mild infections. Based on the simulation results of unit cost calculations for general polyclinics and dental clinics in tables 2 and 3, there are several simulation results. For example, for direct costs for general polyclinic services, the resulting cost calculation is as follows: treatment with non-generic drugs has an estimated price of IDR 35,000; generic treatment has an estimated price of IDR 6,356. The total needs per patient can be used as the basic benchmark for determining the tariff for the primary healthcare centers. An analysis of the service rates for Individual Health Efforts (Upaya Kesehatan Perseorangan) at the Central Cimahi Health Center could be conducted. An individual health effort is an activity and/or a series of health service activities aimed to improve, prevent, cure, and reducing suffering due to disease, as well as restoring individual health.

In this study, a simulation of the calculation of individual health effort activities were conducted at the general and dental polyclinic at the Central Cimahi Health Center by calculating the costs for health services conducted by each health polyclinic. The costs were divided into 2 major groups, namely: direct costs, which can be defined as costs that can be traced directly to each unit of output produced in the production of goods/services. Based on this study's field research and interview results, it was found that the costs that can be traced directly are as follows: costs of services, costs of materials and medicines, costs of laboratory consumables, and costs of medical equipment consumables. According to Subirman (2013), the amount components of variable operational costs are influenced by the number of uses. For example, drugs and medical consumables are influenced by the number of patients, and telephone and water expenditure are also influenced by the number of uses and are directly related to the number of patients.

\section{Indirect Costs Analysis}

The allocation of indirect costs per health service action is calculated by adding up the total indirect costs charged to the polyclinic then divided by the number of actions produced in a period. Based on table 7 , the calculation of average patient visits is as follows: $57,659 / 312=184.8=185$ people/day $-30=155$ people $\times 312=$ 48,360 . Working days $=26 \times 12=312$ days (deducted by 30 dental patients/day). For the indirect costs in general polyclinic services, the resulting cost calculation is as follows: the total indirect costs are IDR $1,304,427,044$ with a total of 48,360 actions and the generated and unit costs are IDR 26,973. The unit cost at the General Polyclinic is IDR 62,529 for treatment with severe infections and IDR 3,329 for the treatment of mild infections.

\section{Comparitive Analysis of Retribution with Other Cities}

Based on Table 5, Cimahi City rates are still above the rates of Bandung City, Cirebon City, and West Bandung Regency. The average tariff proposed by the primary healthcare center in Cimahi City is IDR 8,500. The proposed tariff is still relatively cheap because based on the results of interviews with patients, patients have agreed to increase the general polyclinic tariff if theire is also an increase in health services. The average rate of respondents' willingness and ability to pay is in the range of less than IDR 10,000, meaning that people are still willing and able to pay with the proposed tariff of IDR 8,500 , on the condition that there is an increase in health facilities and services at the primary healthcare centers. Those who do not participate in the Social Security Agency for Health want the primary healthcare centers tariff not to be increased, and for it to still be at IDR 5000 .

From the analysis above, the increase in average tariff proposed ranges from IDR 5000 to IDR 8,500, which can still be affordable because the tariff is still below the purchase price for daily 
consumption/food. However, what needs to be considered is the level of education and income of the people receiving treatment from the health center. Based on interviews and questionnaires, the highest level of education of the people who visit the primary healthcare centers for treatment are junior high and high school and some did not participate in the Social Security Agency for Health. When the tariff is planned to be increased, the primary healthcare center will promote community participation in the Social Security Agency for Health .

For the city of Yogyakarta, the treatment tariff was increased from IDR 5000 to IDR 22,000. This is a comparison for the city of Cimahi to increase their tariff to adjust to the increase in the price of medical devices, the income level of the population, as well as the level of ability and willingness to pay by the community. The proposed health service retribution rates are shown in table 9, whereby the proposed general poly tariff is in the range of IDR 8,500 to IDR 11,000.

\section{CONCLUSION}

The retribution rates for primary healthcare centers in Cimahi City were compared with tariffs in other cities. Each city has a different tariff range, depending on the subsidy policy, the total need for other supporting costs, and the people's ability to pay. Based on the tariffs for the four cities, the general polyclinic tariff is in the range of IDR 2000 to IDR 4000. Indirectly, the unit cost of calculating the average patient's medicine needs is IDR 11,507. Changes in health service rates can be conducted according to people's ability to pay and willingness to pay, as well as consider inflation rates, the increase in raw materials/consumables for health service activities, the increase in health equipment, and others. The value of the proposed amendment to the mayor's regulation regarding the retribution for public health services at the Cimahi City Health Center is in the range of IDR 11,000.

\section{REFERENCES}

Akbar, R., Setyaningrum, N. and Estiningsih, D. (2017) 'Study on the Use of Off-Label Drugs in Children at the Sleman Health Center', INPHARNMED Journal (Indonesian Pharmacy and Natural Medicine Journal), 1(1), pp. 21-33.

Bandung City Local Regulation (2010) 'Bandung City Regional Regulation No.3 of 2010 concerning Retribution for Health Services Bandung City'.

Devine, K., O'clock, P. and Lyons, D. (2000) 'Health-care financial management in a changing environment', Journal of Business Research, 48(3), pp. 183-191. doi: 10.1016/S0148-2963(98)00083-6.

Harsetyanto, T. O. P. (no date) 'Formulation of Unit Cost of Health Services for Public Health Centers in the Framework of Formulating Business Plans and Budgets (RBA) for Public Service Agencies (Case Study at Puskesmas Padas, Ngawi Regency)', Jurnal Ilmiah Mahasiswa FEB, 3(1).

Regulation, B. L. (2012) 'Bogor City Regional Regulation No. 4 of 2010 concerning Bogor City Health Service Retribution'

Regulation, C. L. (2011) 'Cimahi City Regulation No. 8 of 2011 concerning the Cimahi City Health Service Retribution', 16(22), pp. 119-128.

Regulation, C. L. (2011) 'Cirebon City Regional Regulation No.3 of 2011 concerning Retribution for Health Services Cirebon City'.

Sabirman (2013) Calculation of Health Service Unit Cost At Community Health Center in Samarinda, in 2012 ( Palaran Case Study 
482 The Indonesian Journal of Public Health, Vol 16, No 3 December 2021:472-482

Community Health Center', Jurnal

166-173.

Ilmu Kesehatan Masyarakat, 4, pp. 